\title{
Review of Preparing Adult English Language Learners to Write for College and the Workplace
}

Charles A. MacArthur, University of Delaware

Schaetzel et al. (2019) address the substantial challenges of helping adult English language learners (ELLs) develop the writing knowledge, strategies, and skills required in academic and workplace settings. Reflecting increased demands of the $21^{\text {st }}$ century workplace, recent College and Career Readiness Standards for Adult Education (U.S. Department of Education, 2013) place increased emphasis on academic writing proficiency. Unfortunately, adult education teachers working with ELLs, in general, have not received adequate preparation for teaching writing. Thus, the purpose of the book is to support professional learning by providing practical instructional strategies for writing instruction with ELLs. The audience includes adult education teachers and program managers as well as university instructors and students who are preparing to work with adults learning English.
The editors have substantial research and practical experience in adult education, and they have recruited chapter authors with practical experience working with adult ELLs on writing. One of the challenges for the book is that limited research has addressed writing instruction for adult ELLs or for adult learners in general. The limited emphasis on writing presents a challenge but, at the same time, increases the relevance of the book. The authors base their instructional recommendations on professional practice, available research, and general principles of adult education and literacy research.

The chapters are designed to provide practical advice and support for teaching writing. Each of the 10 chapters describes an instructional approach, and most of them provide detailed support in the form of lesson outlines, materials, additional resources, and questions for self-study and application. 
The book is organized in four sections. The first, "Setting the Stage for Teaching Writing," focuses on integrating writing with reading and oral language development, which has substantial theoretical support from research in K-12 settings. It also advocates the use of content-based learning approaches to developing literacy skills. Section 2, "Supporting the Writing Process," addresses the writing process in general, scaffolding the process, technology support, and feedback. The chapter on feedback is based on fairly extensive research on corrective feedback for ELLs, some of it conducted by chapter author Ferris (2012). It provides clear principles and practices for providing feedback on both content and language. The chapter on scaffolding writing draws in part on the author's own research on the use of dialogue journals (Peyton \& Staton, 1993), which involve written interactions between students and teacher that provide an opportunity to informally guide students in developing their ideas and language skills. The chapter on technology provides an outline for teachers to follow in planning a unit of project-based instruction that culminates in research-supported reports on a meaningful topic (e.g., careers). The outline and instructional recommendations are not specific to adult ELLs, but the suggested technology resources are appropriate. The chapter on the process of writing discusses the general principles of familiar process approaches, though without much specific reference to ELLs.

Section 3 focuses on adults who have limited education and literacy in their home language. The first chapter appropriately stresses the importance of teaching early reading and writing skills in the context of meaningful activities; however, the specific recommendations for developing word recognition skills are not consistent with research showing the value of systematic phonics instruction with ELL adults (Alamaprese et al., 2011). The chapter on building on oral language skills to develop writing presents four sample instructional units for students from high beginning to advanced English as a second language classes, all of which use oral language and reading in the process of conducting research and presenting the results in written reports. Even at the lowest level, the examples show learners engaged in collecting data - interviewing peers, graphing the results, and collaboratively writing a report with the support of sentence frames.

One evidence-based instructional approach that is missing from the book is strategy instruction. Substantial research supports the value of strategy instruction in writing with elementary and secondary students, and with adult education and college students (Traga Philippakos \& MacArthur, 2019). Over 10 years of research by Olson et al. (2020) has demonstrated positive effects of strategy instruction in large scale studies in high schools with large proportions of ELLs.

Overall, the book is a valuable resource for professional learning about the important goal of improving instruction in writing for adult ELLs. Research on instruction in this area is limited, but the instructional recommendations, with few exceptions, are supported by available research, professional practice, and general principles of adult education and literacy research. The book provides practical recommendations and clear detailed descriptions of instructional approaches as well as references to additional sources. It would fit in university classes on literacy instruction for ELLs at the high school or adult levels; it would also be useful in professional learning communities at adult education settings. 


\section{References}

Alamprese, J. A., MacArthur, C. A., Price, C., \& Knight, D. (2011). Effects of a structured decoding curriculum on adult literacy learners' reading development. Journal of Research on Educational Effectiveness, 4, 152-174. https://doi.org/10.1080/19345747.2011.555294

Ferris, D. R. (2012). Written corrective feedback in second language acquisition and writing studies. Language Teaching Research, 45, 446-459.

Traga Philippakos, Z. A. \& MacArthur, C. A. (2019). Writing strategy instruction for low-skilled postsecondary students. In D. Perin (Ed.), Wiley handbook of adult literacy (pp. 495-516). Wiley.
Olson, C. B., Woodworth, K., Arshan, N., Black, R., Chung, H. Q., D’Aoust, C., Dewar, T., Friedrich, L., Godfrey, L., Land, R., Matuchniak, T., Scarcella, R., \& Stowell, L. (2020). The pathway to academic success: Scaling up a text-based analytical writing intervention for Latinos and English learners in secondary school. . Journal of Educational Psychology, 701-717. https://psycnet.apa. org/doi/10.1037/edu0000387

Peyton, J. K., \& Staton, J. (1993). Dialogue journals in the multilingual classroom: Building language fluency and writing skills through written interaction. Ablex.

U.S. Department of Education, Office of Vocational and Adult Education. College and Career Readiness Standards for Adult Education. Washington, D.C., 2013. 